\title{
Molecular characterisation of Bartonella species in cats from São Luís, state of Maranhão, north-eastern Brazil
}

\author{
Maria do Socorro Costa de Oliveira Braga', ${ }^{1,}$, Pedro Paulo Vissotto de Paiva Diniz ${ }^{3}$, \\ Marcos Rogério André1, Caroline Plácidi de Bortoli', Rosangela Zacarias Machado ${ }^{1 /+}$ \\ 1Departamento de Patologia Veterinária, Faculdade de Ciências Agrárias e Veterinárias, \\ Universidade Estadual Paulista, Jaboticabal, SP, Brasil Universidade Estadual do Maranhão, São Luís, MA, Brasil \\ ${ }^{3}$ College of Veterinary Medicine, Western University of Health Sciences, Pomona, CA, USA
}

Bartonella species are fastidious bacteria that predominantly infect mammalian erythrocytes and endothelial cells and cause long-lasting bacteraemia in their reservoir hosts. Reports that describe the epidemiology of bartonellosis in Brazil are limited. This study aimed to detect and characterise Bartonella spp DNA from cat blood samples in São Luís, Maranhão, north-eastern Brazil. Among 200 cats tested for multiple genes, nine (4.5\%) were positive for Bartonella spp: six cats for Bartonella henselae and three for Bartonella clarridgeiae. Based on the phylogenetic analysis of four genes, the B. henselae strain matched strains previously observed in Brazil and was positioned in the same clade as B. henselae isolates from the United States of America. Moreover, sequence alignment demonstrated that the $\mathrm{B}$. clarridgeiae strain detected in the present study was the same as the one recently detected in cats from southern Brazil.

Key words: Bartonella henselae - Bartonella clarridgeiae - cats - north-eastern Brazil

Bartonella species are fastidious Gram-negative bacteria that predominantly infect mammalian erythrocytes and endothelial cells and cause long-lasting bacteraemia in their reservoir hosts (Chomel et al. 2004). Bartonellae are usually vector-borne bacteria and the vector varies depending on the bacterial species, host and reservoir (Chomel et al. 2006b).

Domestic cats are the main reservoir for Bartonella henselae (the most frequent agent of cat scratch disease), Bartonella clarridgeiae (suspected in a few cases of cat scratch disease) (Chomel et al. 2004) and Bartonella koehlerae (Avidor et al. 2004).

There are few reports of Bartonella infection in Brazil. A low seroprevalence of Bartonella spp has been detected among Brazilian dogs (Diniz et al. 2007a, b) and $B$. henselae and Bartonella vinsonii berkhoffii DNA has been detected in Brazilian dogs at a very low prevalence (Diniz et al. 2007b). Conversely, a very high prevalence of antibodies to $B$. henselae has been observed among free-ranging wild felids in Brazil (Filoni et al. 2006) and the parasite has been detected in wild felids by molecular techniques (Guimarães et al. 2010). Recently, a seroprevalence for Bartonella spp of $35.7 \%$ was observed among cats belonging to human immunodeficiency virus (HIV) antibody-positive individuals (Lamas et al. 2010). In addition, Bartonella spp have been molecularly detected in cats from the states of Rio Grande do Sul (RS) (Staggemeier et al. 2010) and Rio de Janeiro (RJ) (Souza et al. 2010, Crissiuma et al. 2011).

\footnotetext{
Financial support: CNPq (\#479162/2007-7), WesternU

+ Corresponding author: zacarias@fcav.unesp.br

Received 21 November 2011

Accepted 14 March 2012
}

There are few studies addressing the occurrence of Bartonella spp in humans in Brazil. Antibodies to $B$. henselae and Bartonella quintana have been detected in $13.7 \%$ and $12.8 \%$ of healthy residents of the state of Minas Gerais (MG), respectively (da Costa et al. 2005). A seroprevalence of Bartonella spp of $38.4 \%$ and $34.4 \%$ has been observed in HIV-positive patients and healthy human populations, respectively, in Jacarepaguá, RJ (Lamas et al. 2010).

This study aimed to detect and characterise Bartonella spp DNA from Brazilian cat blood samples from São Luís, Maranhão (MA), north-eastern Brazil.

\section{MATERIALS AND METHODS}

Sample collection and study area - Between October 2008-January 2009, whole blood samples were collected from 200 domestic cats (102 males, 98 females) that were allowed outside in São Luís (194 cats from suburban areas of São Luís county and six from Raposa county). The study region is an invasion area that has suffered a $70 \%$ forest reduction. Cats were selected without specific inclusion criteria and were apparently healthy at the time of sample collection. Sampled cats had contact with other cats and dogs. Blood samples for polymerase chain reaction (PCR) were collected from jugular or cephalic veins, immediately aliquoted into tubes containing ethylenediamine tetraacetic acid (EDTA) as an anticoagulant and stored at $-20^{\circ} \mathrm{C}$ until PCR analysis. All procedures were performed according to Ethical Principles in Animal Research adopted by the Brazilian College of Animal Experimentation and were approved by the Ethical Committee of the College of Agricultural Sciences and Veterinary, São Paulo State University (UNESP) Jaboticabal, state of São Paulo (SP) (2008/025862-07). 
$P C R$ - DNA was extracted from $200 \mu \mathrm{L}$ of EDTA-anticoagulated blood with the QIAamp DNA Blood Mini kit (Qiagen, Valencia, CA, USA) according to the manufacturer's instructions. The DNA was eluted in $200 \mu \mathrm{L}$ of EB Buffer (supplied by the DNA extraction kit).

Bartonella genus screening was performed by PCR in which the intergenic transcribed spacer (ITS) was targeted, as described previously (Diniz et al. 2007a). Amplification was performed by conventional PCR in a $25 \mu \mathrm{L}$ final reaction volume that contained $1 \mathrm{X}$ PCR mix (Premix Ex Taq, Takara Bio Inc, Shiga, Japan), 12.5 pmol each primer (Integrated DNA Technologies Inc, Coralville, IA) and 5.0 $\mu$ L DNA template. PCR was performed in a thermocycler (Mastercycler Pro Gradient S, Eppendorf, Hamburg, Germany) under the following conditions: a single hot-start cycle at $95^{\circ} \mathrm{C}$ for $2 \mathrm{~min}$, followed by 55 cycles of denaturing at $94^{\circ} \mathrm{C}$ for $15 \mathrm{~s}$, annealing at $66^{\circ} \mathrm{C}$ for $20 \mathrm{~s}$ and extension at $72^{\circ} \mathrm{C}$ for $20 \mathrm{~s}$. Amplification was completed by an additional cycle at $72^{\circ} \mathrm{C}$ for 1 min and products were resolved in a $1.5 \%$ agarose matrix by electrophoresis and analysed under ultraviolet exposure. DNA from a healthy, pathogen-free cat was used as a PCR negative control. DNA extracted from B. quintana (similar to GenBank accession L35100) was used as a positive control. To prevent PCR contamination, the sample extraction, reaction setup, PCR amplification and amplicon detection were performed in separate areas.

Additionally, when genomic material was available, samples were evaluated for the presence of five additional genes: the bacteriophage-associated heme-binding protein gene (pap31) (Diniz et al. 2007a), the RNA polymerase beta subunit gene (rpoB) (Diniz et al. 2007a), the riboflavin synthase gene (ribC) (Johnson et al. 2003), the heat shock protein gene ( $g r o E L)$ (Barber et al. 2010) and the citrate synthase gene ( $g l t A)$. The gltA gene was amplified with primers BhCS.781p 5'-GGGGACCAGCTCATGGTGG-3' (Norman et al. 1995) and BvCS.205p 5'-TT-
TATCGYGGTTATCCTATYG-3' (Winoto et al. 2005). The amplification conditions were similar to those used for the ITS, but different annealing temperatures were used for each primer pair: $62^{\circ} \mathrm{C}$ for pap 31 and $r p o B, 55^{\circ} \mathrm{C}$ for ribC and gltA and $58^{\circ} \mathrm{C}$ for groEL.

Phylogenetic analysis - Amplicons were gel-purified or PCR-purified (MiniElute kit, Qiagen, Valencia, CA, USA) and sequenced by the Department of Technology UNESP or by Eurofins MWG Operon (Huntsville, AL, USA). Chromatogram evaluations, primer deletions and sequence alignments were performed with the software Contig-Express and AlignX (Vector NTI Suite 10.1, Invitrogen Corp, Carlsbad, CA, USA). Bacterial species and strain types were defined by comparison with other sequences deposited in the GenBank database with the Basic Local Alignment Search Tool (Altschul et al. 1990). Phylogenetic analysis was performed with concatenated sequences of the ITS, $r p o B$, ribC and glt $A$ genes with the maximum likelihood method based on the Kimura twoparameter model (Kimura 1980) with MEGA4 software (Tamura et al. 2007). The pap31 and groEL sequences were excluded from the concatenated phylogenetic analysis because the available DNA sequences in GenBank from other Bartonella species were limited.

\section{RESULTS}

Among 200 cats tested for multiple genes, nine (4.5\%) were positive for Bartonella spp: six for B. henselae (4 males, 2 females) and three for $B$. clarridgeiae (1 male, 2 females) (Table). These isolates were positioned in the same clade as other $B$. henselae isolates from dogs and humans from Brazil and the United States of America (USA) and the B. clarridgeiae isolate from a cat from the USA, with high bootstrap support (100/100). Sixty (30\%) of the cats were parasitized by fleas (Ctenocephalides felis), including cats positive for Bartonella spp.

TABLE

Species of Bartonella identified in five cats by DNA amplification and sequencing from São Luis, state of Maranhão, Brazil

\begin{tabular}{lcccccc}
\hline & \multicolumn{5}{c}{ Genes targeted for Bartonella detection and characterization } \\
\cline { 2 - 7 } Cat number & ITS & rpoB & pap31 & ribC & gltA & groEL \\
\hline 3 & B.h. & B.h. & B.h. & B.h. & B.h. & NT \\
6 & B.h. & B.h. & B.h. & B.h. & B.h. & NT \\
7 & - & - & - & B.c. & - & B.c. \\
8 & B.c. & - & - & B.c. & NT & NT \\
10 & B.h. & B.h. & B.h. & B.h. & B.h. & B.h. \\
109 & B.h. & - & B.h. & B.h. & B.h. & BT \\
120 & B.h. & - & B.h. & B.h. & NT & NT \\
134 & B.h. & - & - & - & - & NT
\end{tabular}

B.c.: Bartonella clarridgeiae; B.h.: Bartonella henselae; gltA: citrate synthase gene; groEL: hear shock protein gene; ITS: intergenic transcriber spacer; NT: not tested due to insufficient genomic material; pap31: bacteriophage-associated heme-binding protein gene; $r i b C$ : riboflavin synthase gene; $r p o B$ : RNA polymerase beta subunit gene. 
We deposited several partial B. henselae Brazil-1 sequences into the GenBank database, including HQ012581 (ITS), HQ012584 (rpoB), HQ012582 (pap31), HQ012583 (ribC), HQ012580 (gltA) and HQ704721 (groEL). Additionally, several B. clarridgeiae sequences were deposited, including HQ012586 (rpoB), HQ012585 (ribC) and HQ704720 (groEL).

\section{DISCUSSION}

The ITS and $r p o B$ sequences obtained from three cats infected with $B$. henselae were $100 \%$ homologous (ITS $=546 / 546 \mathrm{bp}, \mathrm{rpoB}=585 / 585 \mathrm{bp})$ to sequences of the $B$. henselae Brazil-1 strains previously detected from a 36-year-old, HIV antibody-positive Brazilian male with severe anaemia, panserositis, ascitis and cryptogenic hepatitis (Velho et al. 2007) and from a dog in Brazil with fever, severe anaemia, thrombocytopenia and myocarditis (Diniz et al. 2007a). In addition, the partial pap31 sequence obtained from these three cats was $100 \%$ homologous (490/490 bp) to the $B$. henselae Brazil-1 strain detected from the sick dog (Diniz et al. 2007a), but could not be compared to the human case because pap31 sequences were not obtained in that reported case (Velho et al. 2007). This is the first description of this $B$. henselae strain infecting cats in Brazil and these results may represent an important aspect of the epidemiology of this organism. The entire genome sequence of the $B$. henselae Brazil-1 strain is not available, but based on the phylogenetic analysis of the four genes (Figure), this strain is positioned in the same clade as other $B$. henselae isolates. Because the cats evaluated in this study are located in a distinct region of Brazil, approximately $2.880 \mathrm{~km}$ (1.789 miles) from the region in which the human and canine cases were originally reported, the $B$. henselae Brazil-1 strain may represent the endogenous $B$. henselae strain of Brazil. A recent study in the Southern region of Brazil detected two B. henselae-infected cats with $r i b C$ sequences similar to the Brazil-1 strain (HM588661 and HM588662); however, other genes were not amplified and sequenced (Staggemeier et al. 2010). Our results expand the molecular characterisation of the $B$. henselae Brazil-1 strain, with partial ribC (536 bp), gltA (915 bp) and groEL (565 bp) gene sequences that were not available for the human or canine cases previously reported. These new DNA sequences provide important data for future multilocus sequence analysis and phylogenetic studies of $B$. henselae strains.

Three cats were infected with $B$. clarridgeiae and the sequences of the $r p o B$, ribC and groEL genes from two of these cats revealed that this species was $100 \%$ homologous to a strain of B. clarridgeiae (ATCC 51734) that was isolated from a kitten in Texas, USA (Clarridge et al. 1995). Moreover, it was also similar to a strain of $B$. clarridgeiae (CIP 104772) that was isolated from a cat in Strasbourg, France (Lawson \& Collins 1996). Multiple sequence alignments of the $r i b C$ gene demonstrated that these two cats from the north-eastern region of Brazil were infected with the same strain recently detected from one of three cats infected with B. clarridgeiae in the southern region of Brazil (HM588660) (Staggemeier et al. 2010). In addition, unpublished DNA sequences de- posited in GenBank indicate that the same sequence was identified in China (EU571943 and EU836705), although the host species was not indicated.

Fleas are responsible for the transmission of $B$. henselae and B. clarridgeiae among cats (Chomel et al. 1996, Foil et al. 1998). Thirty percent of the cats sampled in this study were infested with C. felis (including those positive for Bartonella spp by PCR), but were apparently healthy at the moment of blood collection. An increasing number of arthropod vectors, including keds, lice, biting flies, sandflies and ticks, have been observed or suspected to be associated with the transmission of Bartonella spp among animal populations (Breitschwerdt et al. 2010a). Although numerous molecular surveys have detected Bartonella DNA in ticks, predominantly in dogs and humans, there is little evidence that Bartonella spp can replicate within ticks and no definitive evidence of transmission by a tick to a vertebrate host (Angelakis et al. 2010). Although vertical transmission of Bartonella spp among natural rodent hosts has been confirmed (Kosoy et al. 1998), B. henselae is not transmitted transplacentally, via colostrum or milk, or venereally, among

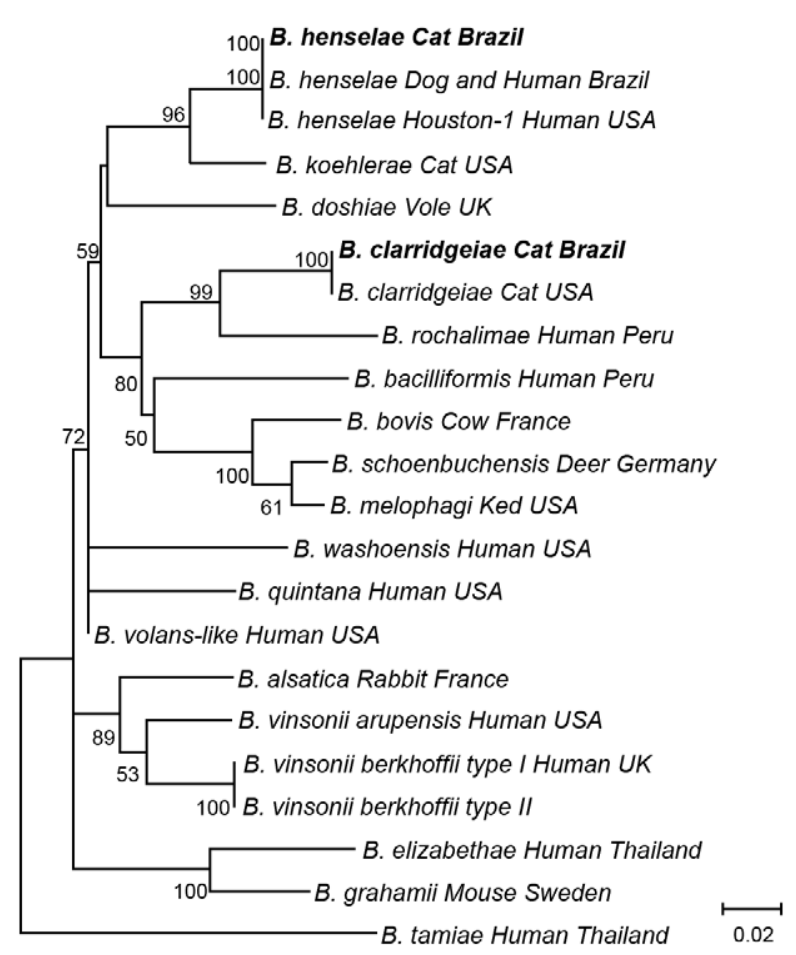

Phylogenetic tree based on concatenated partial sequences of intergenic transcriber spacer, RNA polymerase beta subunit gene, riboflavin synthase gene and citrate synthase gene of Bartonella henselae and Bartonella clarridgeiae detected from cats in Brazil (herein indicated in boldface) compared to other Bartonella species described infecting human beings by using maximum likelihood method based on the Kimura two-parameter model. The number at nodes indicates percentages of bootstrap support based on 1,000 replicates. Percentages corresponding to partitions reproduced in less than $50 \%$ bootstrap replicates are collapsed. Scale bar indicates 0.02 substitutions per nucleotide position. Evolutionary analyses were conducted in MEGA4 software (Tamura et al. 2007). 
cats (Abbott et al. 1997, Guptill et al. 1998). Blood transfusion is another route of Bartonella spp transmission among cats (Kordick et al. 1999).

Cats may be more likely to exhibit clinical symptoms upon infection with a non-reservoir-adapted Bartonella species (Breitschwerdt et al. 2010a). Bartonella spp induces asymptomatic infection in preferred hosts, behaving like a stealth pathogen (Kordick \& Breitschwerdt 1998). However, Bartonella infections in cats have been associated in some cases with fever, lethargy, anorexia, reproductive failure, lymphadenopathy, stomatitis, uveitis, endocarditis and neurological dysfunction (Glaus et al. 1997, Guptill et al. 1998, Lappin \& Black 1999, Breitschwerdt et al. 2010a, Dowers et al. 2010).

Several Bartonella species are considered zoonotic, including $B$. henselae and $B$. clarridgeiae. Cats are the primary reservoir for $B$. henselae and likely $B$. clarridgeiae and are the transmission vector for human infection. The most frequent infection route to humans is through scratches contaminated with flea faeces (Chomel et al. 1996). Cat bites are a less likely route, as shedding of $B$. henselae in cat saliva has not been clearly documented (Chomel et al. 2006a). Recently, evidence for $B$. vinsoniii subsp. berkhoffii and $B$. henselae transmission to children in utero or during caesarean section has been reported (Breitschwerdt et al. 2010b). In addition, the ability of $B$. henselae to adhere and invade mature human erythrocytes (Pitassi et al. 2007) and remain viable in red blood cells after 35 days of storage at $4^{\circ} \mathrm{C}$ (Magalhães et al. 2008) underscore the possibility that these organisms may be transmitted by blood transfusion (Magalhães et al. 2009, Velho 2009). Although immunocompromised patients may present with a systemic and fatal disease, immunocompetent individuals infected with Bartonella spp may develop non-specific and usually non-life-threatening clinical symptoms that have a significant impact on quality of life (Breitschwerdt et al. 2008, 2010a, b, Kaiser et al. 2011, Kalogeropoulos et al. 2011). Epidemiologic data on human bartonellosis in Brazil is very limited. Among 457 healthy adults in the countryside of MG, $13.7 \%$ and $12.8 \%$ harboured $B$. henselae and B. quintana (cut-off titre of 64), respectively (da Costa et al. 2005). Another study in a semi-rural area of RJ detected Bartonella spp seroprevalences of $38.4 \%$ and $34.4 \%$ (cut-off titre of 20 ) among 125 asymptomatic HIV-positive patients and 125 blood donors (Lamas et al. 2010). In this study, contact with cats was identified as a risk factor for Bartonella exposure. Clinical cases associated with high $\mathrm{IgG}$ titres against Bartonella spp have been reported in Brazil, including two fatal cases of culture-negative endocarditis (Siciliano et al. 2006) and one asymptomatic case (Lamas et al. 2007). Additionally, a 40-year-old man tested seropositive for Bartonella spp, likely from a cat scratch, which was complicated with aseptic meningitis and neuroretinitis (Pinto Júnior et al. 2008). Ophthalmic findings, including retinal infiltrates, angiomatous lesions, neuroretinitis and visual loss, were associated with general symptoms (fever, lymphadenopathy, spleen and liver enlargement and rash) in cat scratch disease cases diagnosed in human patients who were seropositive for Bartonella spp (Curi et al. 2010).
The percentage of Bartonella spp-positive cats identified by PCR in the present study was lower than that in other regions of Brazil. For example, a molecular study of cats from RS observed that $17 \%$ of 47 feral cats were infected with Bartonella spp; five $(10.6 \%)$ were infected with $B$. henselae and three (6.4\%) were infected with $B$. clarridgeiae (Staggemeier et al. 2010). Most cats from an animal shelter in city of Vassouras, RJ were infected (97.3\% PCR-positive) (Souza et al. 2010). Recently, B. henselae DNA and antibodies to Bartonella spp were detected in $42.5 \%$ and $47.5 \%$ of cats, respectively, undergoing neutering or spaying in RJ (Crissiuma et al. 2011).

Further detection and genetic sequencing of Bartonella species from multiple areas in Brazil is needed to more precisely characterise their geographic distribution, prevalence, new hosts and reservoirs and zoonotic impact.

\section{ACKNOWLEDGEMENTS}

To Dr Ricardo Maggi, for sharing unpublished sequences of Bartonella species for phylogenetic comparison.

\section{REFERENCES}

Abbott RC, Chomel BB, Kasten RW, Floyd-Hawkins KA, Kikuchi Y, Koehler JE, Pedersen NC 1997. Experimental and natural infection with Bartonella henselae in domestic cats. Comp Immunol Microbiol Infect Dis 20: 41-51.

Altschul SF, Gish W, Miller W, Myers EW, Lipman DJ 1990. Basic local alignment search tool. J Mol Biol 215: 403-410.

Angelakis E, Billeter SA, Breitschwerdt EB, Chomel BB, Raoult D 2010. Potential for tick-borne bartonelloses. Emerg Infect Dis 16: 385-391.

Avidor B, Graidy M, Efrat G, Leibowitz C, Shapira G, Schattner A, Zimhony O, Giladi M 2004. Bartonella koehlerae, a new catassociated agent of culture-negative human endocarditis. J Clin Microbiol 42: 3462-3468.

Barber RM, Li Q, Diniz PP, Porter BF, Breitschwerdt EB, Claiborne MK, Birkenheuer AJ, Levine JM, Levine GJ, Chandler K, Kenny P, Nghiem P, Wei S, Greene CE, Kent M, Platt SR, Greer K, Schatzberg SJ 2010. Evaluation of brain tissue or cerebrospinal fluid with broadly reactive polymerase chain reaction for Ehrlichia, Anaplasma, spotted fever group Rickettsia, Bartonella and Borrelia species in canine neurological diseases (109 cases). $J$ Vet Intern Med 24: 372-378.

Breitschwerdt EB, Maggi RG, Chomel BB, Lappin MR 2010a. Bartonellosis: an emerging infectious disease of zoonotic importance to animals and human beings. $J$ Vet Emerg Crit Care (San Antonio) 20:8-30.

Breitschwerdt EB, Maggi RG, Farmer P, Mascarelli PE 2010b. Molecular evidence of perinatal transmission of Bartonella vinsonii subsp. berkhoffii and Bartonella henselae to a child. J Clin Microbiol 8: 2289-2293.

Breitschwerdt EB, Maggi RG, Nicholson WL, Cherry NA, Woods CW 2008. Bartonella sp. bacteremia in patients with neurological and neurocognitive dysfunction. J Clin Microbiol 46: 2856-2861.

Chomel BB, Boulouis HJ, Breitschwerdt EB 2004. Cat scratch disease and other zoonotic Bartonella infections. $J$ Am Vet Med Assoc 224: $1270-1279$.

Chomel BB, Boulouis HJ, Maruyama S, Breitschwerdt, EB 2006a. Bartonella spp in pets and effect on human health. Emerg Infect Dis 12: 389-394.

Chomel BB, Kasten RW, Floyd-Hawkins K, Chi B, Yamamoto K, Roberts-Wilson J, Gurfield AN, Abbott RC, Pedersen NC, Koeh- 
ler JE 1996. Experimental transmission of Bartonella henselae by the cat flea. J Clin Microbiol 34: 1952-1956.

Chomel BB, Kasten RW, Henn JB, Molia S 2006b. Bartonella infection in domestic cats and wild felids. Ann N Y Acad Sci 1078: 410-415.

Clarridge J 3rd, Raich T, Pirwani D, Simon B, Tsai L, RodriguezBarradas M, Regnery R, Zollo A, Jones DC, Rambo C 1995. Strategy to detect and identify Bartonella species in routine clinical laboratory yields Bartonella henselae from human immunodeficiency virus-positive patient and unique Bartonella strain from his cat. J Clin Microbiol 33: 2107-2113.

Crissiuma A, Favacho A, Gershony L, Mendes-de-Almeida F, Gomes R, Mares-Guia A 2011. Prevalence of Bartonella species DNA and antibodies in cats (Felis catus) submitted to a spay/neuter program in Rio de Janeiro, Brazil. J Feline Med Surg 13: 149-151.

Curi AL, Machado D, Heringer G, Campos WR, Lamas C, Rozental T, Gutierres A, Orefice F, Lemos E 2010. Cat-scratch disease: ocular manifestations and visual outcome. Int Ophthalmol 30: $553-558$.

da Costa PS, Brigatte ME, Greco DB 2005. Antibodies to Rickettsia rickettsii, Rickettsia typhi, Coxiella burnetii, Bartonella henselae, Bartonella quintana and Ehrlichia chaffeensis among healthy population in Minas Gerais, Brazil. Mem Inst Oswaldo Cruz 100: 853-859.

Diniz P, Schwartz D, De Morais H, Breitschwerdt E 2007a. Surveillance for zoonotic vector-borne infections using sick dogs from southeastern Brazil. Vector Borne Zoonotic Dis 7: 689-698.

Diniz PP, Maggi RG, Schwartz DS, Cadenas MB, Bradley JM, Hegarty B, Breitschwerdt, E 2007b. Canine bartonellosis: serological and molecular prevalence in Brazil and evidence of co-infection with Bartonella henselae and Bartonella vinsonii subsp. berkhoffii. Vet Res 38: 697-710.

Dowers KL, Hawley JR, Brewer MM, Morris AK, Radecki SV, Lappin MR 2010. Association of Bartonella species, feline calicivirus and feline herpesvirus 1 infection with gingivostomatitis in cats. J Feline Med Surg 12: 314-321.

Filoni C, Catao-Dias JL, Bay G, Durigon EL, Jorge RS, Lutz H, Hofmann-Lehmann R 2006. First evidence of feline herpesvirus, calicivirus, parvovirus and Ehrlichia exposure in Brazilian freeranging felids. $J$ Wildl Dis 42: 470-477.

Foil L, Andress E, Freeland RL, Roy AF, Rutledge R, Triche PC, O'Reilly KL 1998. Experimental infection of domestic cats with Bartonella henselae by inoculation of Ctenocephalides felis (Siphonaptera: Pulicidae) feces. J Med Entomol 35: 625-628.

Glaus T, Hofmann-Lehmann R, Greene C, Glaus B, Wolfensberger C, Lutz H 1997. Seroprevalence of Bartonella henselae infection and correlation with disease status in cats in Switzerland. J Clin Microbiol 35: 2883-2885.

Guimarães AM, Brandao PE, Moraes W, Kiihl S, Santos LC, Filoni C, Cubas ZS, Robes RR, Marques LM, Neto RL, Yamaguti M, Oliveira RC, Catão-Dias JL, Richtzenhain LJ, Messick JB, Biondo AW, Timenetsky J 2010. Detection of Bartonella spp in neotropical felids and evaluation of risk factors and hematological abnormalities associated with infection. Vet Microbiol 142: 346-351.

Guptill L, Slater LN, Wu CC, Lin TL, Glickman LT, Welch DF, Tobolski J, Hogen Esch H 1998. Evidence of reproductive failure and lack of perinatal transmission of Bartonella henselae in experimentally infected cats. Vet Immunol Immunopathol 65: 177-189.

Johnson G, Ayers M, McClure SC, Richardson SE, Tellier R 2003. Detection and identification of Bartonella species pathogenic for humans by PCR amplification targeting the riboflavin synthase gene (ribC). J Clin Microbiol 41: 1069-1072.
Kaiser PO, Riess T, O'Rourke F, Linke D, Kempf VA 2011. Bartonella spp: throwing light on uncommon human infections. Int $J$ Med Microbiol 301: 7-15.

Kalogeropoulos C, Koumpoulis I, Mentis A, Pappa C, Zafeiropoulos P, Aspiotis M 2011. Bartonella and intraocular inflammation: a series of cases and review of literature. Clin Ophthalmol 5: 817-829.

Kimura M 1980. A simple method for estimating evolutionary rates of base substitutions through comparative studies of nucleotide sequences. J Mol Evol 16: 111-120.

Kordick DL, Breitschwerdt EB 1998. Persistent infection of pets within a household with three Bartonella species. Emerg Infect Dis 4: 325-328.

Kordick DL, Brown TT, Shin K, Breitschwerdt EB 1999. Clinical and pathologic evaluation of chronic Bartonella henselae or Bartonella clarridgeiae infection in cats. J Clin Microbiol 37: 1536-1547.

Kosoy MY, Regnery RL, Kosaya OI, Jones DC, Marston EL, Childs JE 1998. Isolation of Bartonella spp from embryos and neonates of naturally infected rodents. $J$ Wildl Dis 34: 305-309.

Lamas C, Favacho A, Ramos RG, Santos MS, Ferravoli GI, Weksler C, Rozental T, Bóia MN, Lemos ER 2007. Bartonella native valve endocarditis: the first Brazilian case alive and well. Braz J Infect Dis 11: 591-594.

Lamas CC, Mares-Guia MA, Rozental T, Moreira N, Favacho AR, Barreira J, Guterres A, Bóia MN, de Lemos ER 2010. Bartonella spp infection in HIV positive individuals, their pets and ectoparasites in Rio de Janeiro, Brazil: serological and molecular study. Acta Trop 115: 137-141.

Lappin MR, Black JC 1999. Bartonella spp infection as a possible cause of uveitis in a cat. J Am Vet Med Assoc 214: 1205-1207.

Lawson P, Collins M 1996. Description of Bartonella clarridgeiae sp. nov. isolated from the cat of a patient with Bartonella henselae septicemia. Med Microbiol Letters 5: 64-73.

Magalhães RF, Pitassi LH, Salvadego M, de Moraes AM, BarjasCastro ML, Velho PE 2008. Bartonella henselae survives after the storage period of red blood cell units: is it transmissible by transfusion? Transfus Med 18: 287-291.

Magalhães RF, Urso Pitassi LH, Lania BG, Barjas-Castro ML, Velho PE 2009. Bartonellosis as cause of death after red blood cell unit transfusion. Ultrastruct Pathol 33: 151-154.

Norman AF, Regnery R, Jameson P, Greene C, Krause DC 1995. Differentiation of Bartonella-like isolates at the species level by PCR-restriction fragment length polymorphism in the citrate synthase gene. J Clin Microbiol 33: 1797-1803.

Pinto Júnior VL, Curi AL, Pinto Ada S, Nunes EP, Teixeira M de L, Rozental T, Favacho AR, Castro EL, Bóia MN 2008. Cat scratch disease complicated with aseptic meningitis and neuroretinitis. Braz J Infect Dis 12: 158-160.

Pitassi LH, Magalhães RF, Barjas-Castro ML, de Paula EV, Ferreira MR, Velho PE 2007. Bartonella henselae infects human erythrocytes. Ultrastruct Pathol 31: 369-372.

Siciliano RF, Strabelli TM, Zeigler R, Rodrigues C, Castelli JB, Grinberg M, Colombo S, da Silva LJ, Mendes do Nascimento EM, Pereira dos Santos FC, Uip DE 2006. Infective endocarditis due to Bartonella spp and Coxiella burnetii: experience at a cardiology hospital in São Paulo, Brazil. Ann NY Acad Sci 1078: 215-222.

Souza AM, Almeida DNP, Guterres A, Gomes R, Favacho ARM, Moreira NS, Maia LMP, Rozental T, Torres Filho RA, Cerqueira AMF, Lemos ERF, Almosny NRP 2010. Bartonelose: análise molecular e sorológica em gatos do Rio de Janeiro - Brasil. Rev Bras Cie Vet 17: 7-11. 
Staggemeier R, Venker CA, Klein DH, Petry M, Spilki FR, Cantarelli VV 2010. Prevalence of Bartonella henselae and Bartonella clarridgeiae in cats in the south of Brazil: a molecular study. Mem Inst Oswaldo Cruz 105: 873-878.

Tamura K, Dudley J, Nei M, Kumar S 2007. MEGA4: Molecular Evolutionary Genetics Analysis (MEGA) software version 4.0. Mol Biol Evol 24: 1596-1599.

Velho PE 2009. Blood transfusion as an alternative bartonellosis transmission in a pediatric liver transplant. Transpl Infect Dis 11: 474.
Velho PE, Pimentel V, Del Negro GM, Okay TS, Diniz PP, Breitschwerdt EB 2007. Severe anemia, panserositis and cryptogenic hepatitis in an HIV patient infected with Bartonella henselae. Ultrastruct Pathol 31: 373-377.

Winoto IL, Goethert H, Ibrahim IN, Yuniherlina I, Stoops C, Susanti I, Kania W, Maguire JD, Bangs MJ, Telford SR 3rd, Wongsrichanalai C 2005. Bartonella species in rodents and shrews in the greater Jakarta area. Southeast Asian J Trop Med Public Health 36: 1523-1529. 